\title{
PROSES PENYIDIKAN PERKARA TINDAK PIDANA NARKOTIKA (STUDI KASUS SAT RES NARKOBA POLRESTA SURAKARTA)
}

\author{
Rika Romadzoni, Amir Junaidi. Hafid Zakariya \\ Fakultas Hukum Universitas Islam Batik Surakarta
}

\begin{abstract}
Abstrak
Tujuan dari penelitian ini adalah untuk mengetahui proses pelaksanaan penyidikan terhadap tindak pidana narkotika di Sat Res Narkoba Polresta Surakarta dan untuk mengetahui kendala yang dihadapi oleh penyidik Polri dalam melakukan proses penyidikan tindak pidana narkotika di Sat Res Narkoba Polresta Surakarta. Metode penelitian yang digunakan adalah yuridis empiris. Berdasarkan hasil penelitian dan analisa data dapat disimpulkan bahwa Proses penyidikan perkara tindak pidana narkotika di Sat Res Narkoba Polresta Surakarta yaitu (1) Menerima Laporan (2) Melakukan Tindakan Pertama yaitu setelah menerima laporan dari seseorang maka penyidik melakukan serangkaian penyelidikan dan pembuntutan terhadap seseorang yang dicurigai (3) Penangkapan (4) Penggeledahan (5) Penyitaan (6) Pemeriksaan Tersangka dan Saksi (7) Penahanan (8) Selesainya Penyidikan. Kendala yang di oleh penyidik dalam melakukan penyidikan adalah banyak masyarakat yang tidak mau menginformasikan tentang pengguna narkotika kepada polisi.
\end{abstract}

Kata Kunci : Proses,Penyidik, Narkotika.

\begin{abstract}
The purpose of this research is to know the process of the implementation of the investigation against the crime of narcotics in a drug Polresta Surakarta Reskrim Units and to know the obstacles faced by Police investigators in conducting the process of investigation the Crime Unit in the Narcotics Drug Reskrim Polresta Surakarta. Research methods used are empirical juridical. Based on the results of research and analysis of the data it can be concluded that the process of case investigation of narcotics crime in Drug Polresta Surakarta Reskrim Units namely (1) received a report (2) the first Action after receiving a report from the someone then the investigators conducted a series of investigations and pembuntutan against someone suspected of (3)(4) Arrest Search Seizure (5) (6) the examination of the suspect and Witness Detention (7) (8) the completion of the Investigation. Obstacles in by investigators in conducting investigation is many people who don't want to inform the user about the Narcotics to the police.
\end{abstract}

Key Words: Process, Investigators, Narcotics.

\section{PENDAHULUAN}

Dalam Undang-Undang Dasar Negara Republik Indonesia Tahun 1945 Pasal 1 ayat(3) menerangkan bahwa Negara Indonesia adalah Negara Hukum. Berdasarkan hal tersebut maka Negara Indonesia sangat menjunjung tinggi dan menghormati salah satu pilar negara hukum, yaitu perlindungan dan penghargaan terhadap Hak Asasi Manusia sebagaimana tercantum di dalam Undang-Undang Dasar Negara Republik Indonesia Tahun 1945 Pasal 27 ayat (1) yang berbunyi "Segala warga negara 
bersamaan kedudukannya di dalam hukum dan pemerintahan dan wajib menjunjung hukum dan pemerintahan itu dengan tidak ada kecualinya."

Pembangunan nasional pada hakikatnya adalah pembangunan manusia Indonesia seutuhnya dan pembangunan masyarakat Indonesi seluruhnya dengan berdasarkan Pancasila dan Undang-Undang Dasar Negara Republik Indonesia Tahun 1945. Pembangunan nasional tidak hanya menyangkut pembangunan materiil saja, tetapi juga pembangunan mental spiritual masyarakat Indonesia. Program pembangunan nasional harus bertumpu pada kualitas sumber daya manusia yang perlu ditingkatkan secara terus-menerus termasuk derajat kesehatan.

Untuk mencapai hal tersebut di atas, perlu dilakukan upaya peningkatan di bidang pengobatan dan kesehatan antara lain menjamin ketersediaan Narkoba untuk kepentingan pelayanan kesehatan di sisi lain harus melakukan mencegah, melindungi, dan menyelamatkan bangsa indonesia dari penyalah gunaan Narkotika, memberantas peredaran gelap Narkotika dan Presekutor Narkotika dan menjamin pengaturan upaya rehabilitasi media dan social bagi penyalah Guna dan pecandu Narkotika. ${ }^{1}$

Narkotika adalah zat atau obat yang berasal dari tanaman atau bukan tanaman, baik sintesis maupun semisintesis, yang dapat menyebabkan penurunan atau perubahan kesadaran, hilangnya rasa, mengurangi sampai menghilangkan rasa nyeri, dan dapat menimbulkan ketergantungan.(UU no.35/2009 Pasal 1 ayat(1)). ${ }^{2}$

Menteri memberi izin khusus untuk memproduksi Narkotika kepada Industri Farmasi tertentu yang telah memiliki izin sesuai dengan ketentuan peraturan perundang-undangan setelah dilakukan audit oleh Badan Pengawas Obat dan Makanan. ${ }^{3}$ Peredaran Narkotika meliputi setiap kegiatan atau serangkaian kegiatan penyaluran atau penyerahan Narkotika, baik dalam rangka perdagangan, bukan perdagangan maupun pemindah tanganan, untuk kepentingan pelayanan kesehatan dan pengembangan ilmu teknologi. ${ }^{4}$ Narkotika dalam bentuk obat jadihanya dapat diedarkan setelah mendapatkan izin edar dari Menteri. ${ }^{5}$

Dalam rangka pencegahan dan pemberantasan penyalah gunaan dan peredaran gelap Narkotika dan Prekusor Narkotika, denganUndang-Undang ini dibentuk Badan Narkotika Nasional, yang selanjutnya di singkat BNN.Dan selanjutnya berkoordinasi dengan Kepala Kepolisian Negara Republik Indonesia dalam mencegah dan pemberantasan penyalah gunaan dan peredaran gelap Narkotika dan Prekursor Narkotika. Penyidikan, penuntutan, dan pemeriksaan di sidang pengadilan terhadap penyalah gunaan dan peredaran gelap Narkotika dan Prekursor Narkotika dilakukan berdasarkan peraturan perundang- undangan, kecuali ditentukan lain dalam undangundang.

\section{Rumusan Masalah}

${ }^{1}$ Andi Tentri Wali Putri Takdir Patarai. Proes Penyidikan Tindak Pidana Penyalahgunaan Narkotika.2013.Artikel dalam” Jurnal Hukum Acara Pidana”.No.1.Januari, hal 1-2.

${ }^{2}$ Pasal 1. Undang-Undang No. 35 Tahun 2009.

${ }^{3}$ Pasal 11 ayat(1). Undang-Undang No.35 Tahun. 2009.

${ }^{4}$ Pasal 35. Undang-Undang No.35 Tahun 2009.

${ }^{5}$ Pasal 36.Undang-Undang No.35 Tahun 2009.

Proses Penyidikan Perkara Tindak Pidana Narkotika (Studi Kasus Sat Res Narkoba Polresta Surakarta) 
1. Bagaimana proses penyidikan perkara tindak pidana narkotika di Sat Res Narkoba Polresta Surakarta?

2. Apa kendala yang dihadapi oleh penyidik dalam melakukan penyidikan terhadap tindak pidana narkotika di Sat Res Narkoba Polresta Surakarta?

\section{Tujuan Penelitian}

Maksud dan tujuan yang hendak dicapai dalam penelitian ini adalah:

1. Untuk mengetahui proses pelaksanaan penyidikan terhadap tindak pidana narkotika di Sat Res Narkoba Polresta Surakarta.

2. Untuk mengetahui kendala yang dihadapi oleh penyidik Polri dalam melakukan proses penyidikan tindak pidana narkotika di Sat Res Narkoba Polresta Surakarta.

\section{Manfaat Penelitian}

Dari hasil penelitian tersebut diharapkan mampu memberikan manfaat-manfaat sebagai berikut:

1. Manfaat Teoritis

a. Hasil penelitian dapat digunakan untuk menambah wawasan tentang ilmu pengetahuan di bidang hukum pada umumnya, dan ilmu hukum pidana khususnya mengenai hal yang berkaitan dengan penyidikan tindak pidana narkotika.

b. Dapat dijadikan pedoman dalam penelitian yang lain sesuai bidang penelitian yang penulis teliti.

2. Manfaat Prakmatis

a. Dapat memberikan informasi atau gambaran kepada pihak penyidik khususnya mengenai peraturan hukum dalam rangka penyidikan tindak pidana narkotika.

b. Dapat memberikan masukan pada mereka yang tertarik meneliti masalah ini lebih lanjut.

\section{METODE PENELITIAN}

Istilah "metodologi" berasal dari kata metode guna pengumpulan data yang lengkap dan hasil penelitian yang dapat dipertanggungjawabkan secara ilmiah, maka penelitian ini menggunakan metode sebagai berikut:

1. Lokasi Penelitian

Dalam penelitian ini penulis mengadakan penelitian di Sat Res Narkoba Polresta Surakarta, hal ini disebabkan karena di Sat Res Narkoba Polresta Surakarta Pernah menangani proses penyidikan perkara tindak pidana narkotika, yang berkaitan dengan apa yang akan penulis teliti guna penyusunan skripsi ini.

2. Sifat Penelitian

Penelitian ini bersifat diskriptif, karena penelitian ini berusaha menggambarkan tentang Proses Penyidikan Perkara Tindak Pidana Narkotika Di Sat Res Narkoba Polresta Surakarta, Peneliti hukum diskriptif bertujuan untuk menyajikan gambaran lengkap mengenai setting social atau untuk eksploitasi dari klarifikasi mengenai suatu fenomena atau kenyataan social yang ada.

3. Jenis Penelitian 
Pada penelitian ini menggunakan pendekatan yuridis empiris. Dimaksudkan untuk melihat tindakan dari kepolisian, baik dalam perspektif yuridis yaitu didasarkan pada peraturan perundang-undangan, maupun dalam perspektif empiris yaitu pelaksanaannya oleh Sat Res Narkoba Polresta Surakarta, hingga dapat dilihat apakah sudah mempunyai keserasian dengan hukum in concerto-nya. ${ }^{6}$

4. Jenis Data

Dalam penelitian ini ada dua macam data yang akan dikaji, yaitu data primer dan data sekunder.

a. Data Primer

Adalah data yanag diperoleh langsung dari sumbernya, diamati dan dicatat untuk pertama kalinya data primer tersebut diperoleh dengan observasi yaitu pengumpulan data dengan menggunakan pengamatan langsung pada objek peneliti. Selain itu juga deengan wawancara yaitu salah satu pengumpulan data dengan jalan tanya jawab sepihak yang dikerjakan dengan sistemaatik dan berlandaskan pada tujuan penelitian.

b. Data Sekunder

Yaitu merupakan data yang secara tidak langsung memberikan keterangan bersifat mendukung sumberdata primer. Termasuk dalam sumber data sekunder ini adalah:

1) Bahan Hukum Primer yaitu bahan hukum yang mengikat dan merupakan landasan utama untuk dipakai dalam penelitian ini.

2) Bahan Hukum Sekunder yaitu bahan-bahan hukum yang berupa buku ilmu hukum, jurnal hukum, dan media cetak maupun elektronik.

3) Bahan Hukum Tersier yaitu bahan hukum yang memberikan penjelasan terhadap bahan hukum primer dan bahan hukum sekunder, berupa rancangan undang-undang, kamus dan ensiklopedia.

5. Sumber Data

Sumber data adalah segala sesuatu yang dapat memberikan informasi mengena mengenai data. Berdasarkan sumbernya, dan dibedakan menjadi tiga, yaitu data primer, data sekunder dan data tersier.

a. Sumber Data Primer yaitu data yang diperoleh langsung dari lapangan dengan cara melakukan wawancara dan observasi dengan penyidik di Sat Res Narkoba Polresta Surakarta.

b. Sumber Data Sekunder yaitu merupakan data pendukung dari data primer dalam suatu penelitian hukum empiris yang terdiri dari:

1) Bahan Hukum Primer

Bahan hukum primer merupakan bahan hukum yang mengikat atau yang membuat orang taat pada hukum seperti peraturan perundang-undangan, dan putusan hukum. Bahan hukum primer yang penulis gunakan di dalam penulisan ini yakni Undang-Undang No. 35 Tahun 2009 Tentang Narkotika, Kitab Undang-Undang Hukum Acara Pidana(KUHAP).

2) Bahan Hukum Sekunder

\footnotetext{
${ }^{6}$ Anonim. Metode Penelitian. https://idtesis.com/metode-penelitian-hukum-empiris-dannormatif/. Diakses pada tanggal 21/1/2013.
}

Proses Penyidikan Perkara Tindak Pidana Narkotika (Studi Kasus Sat Res Narkoba Polresta Surakarta) 
Bahan Hukum Sekunder yaitu bahan-bahan hukum yang berupa buku ilmu hukum, jurnal huku, dan media cetak maupun elektronik.

3) Bahan Hukum Tersier

Bahan Hukum Tersier yaitu bahan hukum yang member penjelasan terhadap bahan hukum primer dan bahan sekunder, berupa rancangan undang-undang, kamus,dan eksiklopedia.

6. Teknik Pengumpulan Data

a. Studi Dokumenter

Yaitu teknik pengumpulan data yang tidak langsung ditujukan pada subjek penelitian, namun melalui dokumen. Dokumen yang digunakan dalam penelitian ini adalah mengambil berkas yang ada di Sat Res Narkoba Polresta Surakarta.

b. Wawancara

Wawancara adalah teknik pengumpulan data yang mengajukan pertanyaan langsung oleh pewawancara langsung kepada penyidik, dan jawaban-jawaban akan dicatat atau direkam.

7. Teknik Analisis Data

Teknik analisis data yang digunakan dalam penelitian ini adalah analisis kualitatif adalah suatu cara pemilihan data yang menghasilkan data deskriptif. Pengertian data deskriptif yakni " apa yang dinyatakan responden secara tertulis atau lisan dan juga perilaku nyata yang diamati dan dipelajari secara utuh.

\section{PEMBAHASAN}

\section{Poses Penyidikan Perkara Tindak Pidana Narkotika di Sat Res Narkoba Polresta Surakarta}

Proses penyidikan perkara tindak pidana narkotika adalah suatu sistem atau cara penyidikan yang dilakukan untuk mencari, serta mengumpulkan bukti yang dengan bukti itu membuat terang tentang tindak pidana yang terjadi dan guna menemukan tersangkanya sesuai dengan cara yang di atur dalam KUHAP. ${ }^{7}$

Tindakan penyidikan merupakan suatu tindakan kedua dari proses sistem peradilan pidana setelah tindakan penyelidikan :

\section{Dasar Hukum Penyidikan}

Seperti halnya di Sat Res Narkoba Polresta Surakarta bergerak dengan menggunakan aturan-aturan yang telah ditetapkan undang-undang sebagai acuan. Tak terkecuali dalam hal proses penyidikan, Sat Res Narkoba Polresta Surakarta berdasarkan pada :
a. Pasal 8 ayat (3) dan pasal 10 ayat (1) KUHAP.
b. Undang-undang No.2 Tahun 2002, tentang Kepolisian Republik Indonesia.
c. Peraturan Pemerintah RI No.27 Tahun 1983 Tentang Pelaksanaan KUHAP.

\section{Tahap Penyidikan}

a. Awal Dimulainya Penyidikan

Tahap pertama dalam suatu penyidika adalah membantu rencana penyidikan. Rencana penyidikan ini dibuat agar dari awal dapat ditentukan arah

${ }^{7}$ Andi Tentri Wali Putri Takdir Patarai, Op.Cit.hal. 66. 
dari suatu penyelidikan, cara yang akan digunakan, personil yang akan digunakan, dan jangka waktu yang dibutuhkan dalam suatu penyidikan.

Pembuatan rencana penyidikan adalah suatu keharusan dalam penyidikan terhadap suatu perkara yang akan dilaksanakn oleh penyidik.

Ada beberapa kegunaan dari membuat rencan penyidikan yaitu :

1) Memberikan gambaran mengenai penyidikan yang akan dilakukan pembetulan apabila tindakan yang akan dilakukan sehingga dapat dilakukan pembetulan apabila tindakan yang akan dilakukan oleh penyidik tidak sesuai dengan takti dan dan teknik dalam penyidikan.

2) Merupakan proses control oleh atasan penyidik terhadap penyidikan terhadap penyidikan yang akan dilakukan oleh penyidik.

3) Mencegah terjadinya bias dan penyalahgunaan wewenag oleh penyidik dalam penyelidikan. ${ }^{8}$

b. Tujuan Penyidikan

Adapun tujuan daripada penyidikan adalah untuk mendapatkan atau mengumpulkan keterangan, bukti atau data-data yang akan digunakan untuk :

1) Membuat terang tindak pidana yang terjadi.

2) Siapa yang dapat dipertanggungjawabkan (secara pidana) terhadap tindak pidana tersebut. ${ }^{9}$

c. Sasaran Penyidikan

Berdasarkan uraian di atas, maka dapat ditentukan sasaran penyidikan yang dilakukan oleh Sat Res Narkoba Polresta Surakarta, yaitu :

1) Membuat terang tindak pidana yang terjadi.

2) Siapa yang dapat dipertanggungjawabkan (secara pidana terhadap tindak pidana tersebut).

3) Tempat daerah dimana suatu kejahatan telah dilakukan. ${ }^{10}$

d. Proses penyidikan

Untuk melakukan penyidikan, proses yang dilakukan Sat Res Narkoba Polresta Surakarta yaitu:

1) Menurut Kompol Edy Sulistyanto, Mengenai Proses Penyidikan Perkara Tindak Pidana Narkotika yaitu:

a) Sesuai dengan Standar Operasional Prosedur (SOP).

b) Setelah di lidik petugas menemukan tersangka dan barang buktinya lalu petugas menindak lanjuti dengan proses penyelidikan dan setelah dilakukan penyelidikan petugas melakukan penyidikan dan di dalam penyidikan di situ ada penahan, pemeriksaan BAP dan sebagainya setelah lengkap semua di lanjutkan ke Jaksa Penuntut Umum (JPU) jika JPU di anggap perlu atau bolak - balik dalam arti ada petunjuk-petunjuk dari jaksa maka petugas melengkapi petunjuk tersebut dan setelah cukup atau lengkap di serahkan ke JPU kembali jika sudah lengkap akan muncul surat P21 atau tahap 2(dua) nanti petugas atau penyidik sudah lepas dari

\footnotetext{
${ }^{8}$ Ibid.hal.67.

${ }^{9}$ Ibid.hal. 67-68.

${ }^{10}$ Ibid. hal. 68.
} 
penyidikan dan hasil langsung di sidangkan oleh jaksa maupun hakim yang menghakimi tersangka. ${ }^{11}$

2) Menurut AIPDA Warsino, Mengenai Proses Penyidikan Perkara Tindak Pidana Narkotika yaitu :

Memeriksa tersangka dengan bekerja sama dengan peradilan umum dan dalam melakukan penyelidikan narkotika waktunya dapat di perpanjang menjadi 3X 24 jam dan tersangka di minta untuk di temani oleh seorang pengacara karena hukumanya lebih dari 4 tahun. $^{12}$

3) Menuru Bripka Bayu Prayudanto. Mengenai Proses Penyidikan Perkara Tindak Pidana Narkotika yaitu:

Sama saja seperti penyidikan tindak pidana lainnya hanya saja dalam penyelidikan tindak pidana narkotika diberi waktu selama 3X24 jam sedangkan tindak pidana lainnya hanya 1X24 jam melakukan penyelidikan, contohnya seperti tindak pidana perjudian. ${ }^{13}$

4) Menurut Kompol Widodo. Mengenai Proses Penyidikan Perkara Tindak Pidana Narkotika yaitu :

Sama saja dengan penyidikan perkara tindak pidana lainnya cuman dalam perkara tindak pidana narkotika ini mengacu pada Pasal 111, Pasal 112, Pasal 113, Pasal 114 dan Pasal 127 Undang-undang Nomor 35 Tahun 2009 Tentang Narkotika. ${ }^{14}$

e. Penyidikan

Pada uraian diatas sudah diuraikan bahwa tujuan penyidikan adalah untuk membuat terang suatu tindak pidana dan pelakunya kemudian dilakukan penindakan.

Berdasarkan hasil penelitian mengenai proses penyidikan perkara tindak pidana narkotika yang tersangkanya sdr Deden Darusman Alias Deden.

Adapun tindakan penyidikan perkara tindak pidana narkotika adalah sebagai berikut :

1) Menerima Laporan

Sesuai dengan tugas dan kewajibannya, maka Penyidik harus menerima laporan tentang terjadinya suatu perkara tindak pidana narkotika. Sebagai contoh dalam tindakan nyata adalah pada kasus perkara tindak pidana narkotika jenis shabu milik Sdr. Deden Darusman Alias Deden Bin Momon yang terjadi di dekat Gapura pasar Triwindu Ngarsopuro Kp. K eprabon Rt.01 Rw.01 Kel. Keprabon Kec. Banjaesari Surakarta. Atas kejadian tersebut seorang infoman yang tidak mau disebut namanya memberikan informasi bahwa Deden yang tinggal di Kp. Tanjung Anom Sukoharjo tersebut biasa menjadi kurir atau biasa dimintai tolong untuk mencarikan shabu. ${ }^{15}$ Oktober 2017.

${ }^{11}$ Kompol. Edy Sulistyanto.KASAT RESERSE NARKOBA. Wawancara Pribadi.Surakarta,17

${ }^{12}$ Aipda. Warsino. Penyidik. Wawancara Pribadi. Surakarta,19 Oktober 2017.

${ }^{13}$ Bripka. Bayu Prayudanto. Wawancara Pribadi. Surakarta, 27 Oktober 2017.

${ }^{14}$ Kompol. Widodo. KASAT RESKRIM. Wawancara Pribadi. Surakarta, 24 Oktober 2017.

${ }^{15}$ Dalam Berkas Perkara. No. B/89/I/2017/ Res Narkoba.

Proses Penyidikan Perkara Tindak Pidana Narkotika (Studi Kasus Sat Res Narkoba Polresta Surakarta) 
2) Melakukan Tindakan Pertama

Setelah menerima laporan dari seseorang maka penyidik melakukan serangkaian penyelidikan dan pembuntutan sehingga pada hari Jum'at tanggal 06 Januari 2017 sekitar jam 19.00 Wib saksi bersama team mendapatkan tersangka yang mana tersangka saat itu sedang duduk di bawah tiang lampu gapura pasar triwindu Ngarsopuro Keprabon Surakarta setelah tersangka saksi dekati dan saksi meminta identitas diri berupa KTP ternyata benar bernama DEDEN sesuai dengan informasi yang saksi dapat terkait tersangka biasa menjadi kurir dalam pembelian shabu.

Selanjutnya tersangka saksi geledah badannya belum saksi temukan barang bukti narkoba (sabu) kemudian saksi melihat ada bungkusan plastic (isolasi bening) di dekat tersangka duduk berjarak sekitar 1 (satu) meter dari tersangka duduk kemudian tersangka saksi suruh untuk mengambil bungkusan tersebut dan saksi minta untuk membukanya dan setelah di buka oleh tersangka berisi serbuk kristal putih yaitu shabu, selanjutnyatersangka saksi tanya tentang kepemilikan shabau tersebut dan tersangka mengaku serta menerangkan shabu tersebut miliknya Gendut (belum tertangkap) yang sedianya akan diserahkan oleh tersangka kepada Gendut dengan cara tersangka meletakkan shabu tersebut di atas tegel dekat tersangka duduk di bawah tiang lampu Gapura Pasar Triwindu Ngarsopuro Banjarsari Surakarta, tersangka mengaku hanya sebagai perantara membelikan shabu saja, shabu tersebut sebelumnya di bawa oleh tersangka dari rumahnya Temon dengan naik sepeda angin warna biru dengan cara disimpan dan di kuasai di genggaman tangan kanan tersangka sambil naik sepeda angin tersebut.

Saat di TKP tersangka saksi interogasi menerangkan shabu tersebut di beli dari Johan (belum tertangkap)seharga Rp. 600.000,00 dengan menggunakan uang miliknya Gendut, pada hari Jum'at tanggal 06 Januari 2017 sekitar jam 17.30 Wib melalui perantara Temon tersangka mengaku menerima langsung shabu tersebut dari Johan, sedangkan Temon hanya menelponkan saja kepada Johan untuk datang kerumahnya Temon untuk bertemu dengan tersangka kaitannya tersangka mau membeli shabu.

Bahwa Temon saat saksi tertangkap menerangkan saat tersangka menerima shabu dari Johan saat itu Temon ada di dekatnya tersngka dan Johan namun Temon asyik ngobrol dengan temannya dan Temon mendengar dari penyampaian tersangka sendiri bahwa tersangka sudah menerima shabunya dari Johan.

Selanjutnya tersangka dan Temon saksi di bawa ke Sat Res Narkoba Polresta Surakarta untuk dilakukan pemeriksaan selanjutnya. ${ }^{16}$

3) Penangkapan :

Penangkapan adalah suatu tindakan penyidik berupa pengekangan sementara waktu kebebasan tersangka atau terdakwa apabila terdapat cukup bukti guna kepentingan penyidikan atau penuntutan dan/atau peradilan dalam hal serta menurut cara yang diatur dalam undang-undang ini.

\section{${ }^{16}$ Ibid.}

Proses Penyidikan Perkara Tindak Pidana Narkotika (Studi Kasus Sat Res Narkoba Polresta Surakarta) 
Dasar Hukum Penangkapan adalah Pasal 1 Angka 20 Undang-Undang Nomor 8 Tahun 1981 Tentang Hukum Acara Pidana. ${ }^{17}$

Setelah penyidik menerima laporan atau pengaduan tentang terjadinya suatu perkara tindak pidana narkotika, maka sebagai kelanjutan daripada adanya tindakan yang dilakukan seseorang, apabila penyidik mempunyai dugaan keras disertai bukti-bukti permulaan yang cukup maka penyidik dapat melakukan penangkapan terhadap tersangka.

Penangkapan tidak dapat dilakukan secara sewenang-wenang, karena hal itu melanggar hak asasi manusia. Untuk menagkap seseorang, maka penyidik harus mengeluarkan surat perintah penangkapan disertai alasanalasan penangkapan tersangka dapat menolak petugas yang bersangkutan. Perintah penangkapan tersangka dapat menolak petugas yang bersangkutan. Perintah penangkapan baru dikeluarkan kalau sudah ada dugaan keras telah terjadi tindak pidana disertai pula bukti permulaan yang cukup.

Dengan Surat Perintah Penangkapa Nomor : Sp . Han / 07 / I / 2017 / Res Narkoba, tanggal 06 Januari 2017, telah dilakukan penangkapan terhadap tersangka, tembusan surat perintah penangkapan telah dikirimkan kepada keluarga tersangka. Dan dibuatkan berita acara penangkapan tertanggal 06 Januari 2017. ${ }^{18}$

4) Penggeledahan

Penggeledahan dilakukan setelah diterbitkan Surat Perintah Penggeledahan yang di tandatangani pejabat yang berwenang. Dengan Surat perintah Penggeledahan Nomor: Sp. Dah / 07 / I / 2017 / Res Narkoba, tanggal 06 Januari 2017 telah dilakukan penggeledahan terhadap badan tersangka, setelahnya dibuatkan berita acara penggeledahan, tertanggal 06 Januari 2017 atas penggeledahan tersebut telah dimintakan persetujuan penggeledahan kepada Ketua Pengadilan Negeri Surakarta dan telah mendapatkan penetapan penggeledahan dari Ketua Pengadilan Negeri Surakarta (terlampir). ${ }^{19}$

5) Penyitaan :

Alat-alat atau barang-barang yang di temukan pada saat penggeledahan diamankan atau diadakan penyitaan.

Adapun maksud diadakan penyitaan diperlukan untuk memberikan keyakinan bahwa tersangka yang telah melakukan tindak pidana itu. Pada waktu penyidik akan mengadakan penyitaan suatu barang bukti, maka penyidik terlebih dahulu harus memperlihatkan surat bukti diri, surat tugas dan sebagainya kepada pemilik barang ${ }^{20}$

Dengan Surat Perintah Penyitaan Nomor : Sp. Sita / 07 / I / 2017 / Res Narkoba, tanggal 06 Januari 2017, telah dilakukan penyitaan barang bukti

\footnotetext{
${ }^{17}$ Yudo Saputra. Pengertian Penahanan dan

Penangkapan.http://yudosaputra91.blogspot.co.id/2013/04/pengertian-penahanan-danpenangkapan.html?m=1. Diakses pada tanggal08/4/2013.

${ }^{18}$ Berkas Perkara, Op. Cit.

${ }^{19}$ Berkas Perkara, Op.Cit.

${ }^{20}$ Andi Tentri Wali Putri Takdir Patarai, Op.Cit.hal.73.
}

Proses Penyidikan Perkara Tindak Pidana Narkotika (Studi Kasus Sat Res Narkoba Polresta Surakarta) 
seperti 1 (satu) paket / plastik kecil transparan berisi shabu berat : 0,209 Gram, 1(satu) Unit HP merk Croos warna putih Nomor IM3 : 085799500596, 1 (satu) Sepeda Angin (onthel) warna biru, Sesobek Tissue Warna Putih, Sesobek Isolasi Warna Bening, Setelahnya dibuatkan surat tanda penerimaan dan berita acara penyitaan, tertanggal 06 Januari 2017 atas penyitaan tersebut telah dimintakan persetujuan penyitaan kepada Ketua Pengadilan Negeri Surakarta dan telah mendapatkan penetapan penyitaan dari Ketua Pengadilan Negeri Surakarta (terlampir). ${ }^{21}$

6) Pemeriksaan Tersangka dan Saksi

Pemeriksaan tersangka dan saksi merupakan bagian atau tahap yang paling penting dalam proses penyidikan. Dari tersangka dan saksi akan diperoleh keterangan-keterangan yang akan dapat mengungkap akan segala sesuatu tentang tindak pidana yang terjadi.

Sehubungan dengan itu sebelum pemeriksaan dimulai, penyidik perlu mempersiapkan segala sesuatu yang diperlukan apakah pemeriksa tersangka atau saksi telah ditunjuk orangnya, dimana tersangka atau saksi akan diperiksa dan apakah tersangka atau saksi yang akan diperiksa telah dipanggil sesuai ketentuan yang berlaku.

Persiapan-persiapan yang dimaksud antara lain adalah :

a) Penunjukan penyidik pemeriksa

b) Persiapan bahan-bahan

c) Persiapan tempat pemeriksaan

d) Persiapan sarana pemeriksaan

Apabila persiapan untuk melakukan pemeriksaan telah dipersiapkan, maka pemeriksaan dapat segera dimulai. Kemampuan penyidik pemeriksa sangat menentukan sehingga pemeriksaan yang dilakukan dapat mencapai sasaran yang dikehendaki.

Dalam rangkan melakukan pemeriksaan terhadap tersangka, maka penyidik harus memenuhi ketentuan-ketentuan yang diatur dalam Pasal 51, Pasal 53, Pasal 114, Pasal 115, dan Pasal 133 KUHAP.

Dalam saksi merupakan suatu alat bukti yang sangat menentukan dalam proses peradilan. Karena saaksi itu adalah seseorang dapat memberikan keterangan tentang telah terjadi sesuatu tindak pidana, dimana ia mendengar, melihat dan mengalami sendiri peristiwa tersebut.

Saksi diperiksa secara tersendiri, tetapi boleh dipertemukan yang satu dengan yang lain dan mereka wajib memberikan keterangan yang sebenarnya. ${ }^{22}$

Dalam kasus ini saksi yaitu Wahyu Vidya Pramono,Fredi Dwi Harnanto, Muhammad Taufiq Romadhon Alias Temon, Slamet Padmojo, dan tersangka Deden Darusman Alias Deden.

Saksi Wahyu Vidya Pramono,Fredi Dwi Harnanto memberi keterangan bahwa benar mereka benar bahwa barang bukti berupa : 1 (satu) paket / plastic kecil berisi shabu terbungkus isolasi bening di lapisi tissue

\footnotetext{
${ }^{21}$ Berkas Perkara, Op.Cit.

${ }^{22}$ Andi Tentri Wali Putri Takdir Patarai, Op.Cit.hal. 74-77.
} 
putih tersebut saat di temukan saksi di atas berjarak sekitar 1(satu) meter dari tersangka duduk di dekat gapura pasar triwindu Ngarsopuro tersebut.

Berdasarkan keterangan Muhammad Taufiq Romadhon Alias Temon member keterangan bahwa benar bahwa saksi baru kali ini dimintai tolong oleh Deden untuk dihubungkan kepada Johan untuk membeli shabu sebelumnya saksi belum pernah.

Berdasarkan keterangan Tersangka Deden Darusman Alias Deden memberikan keterangan bahwa benar saat tersangka ditangkap petugas kepolisian pada hari Jum'at tanggal 06 Januari 2017 sekitar jam 19.00 Wib di dekat gapura pasar triwindu Ngarsopuro Kp. Keprabon Rt.01 Rw.1 Kl. Keprabon Kec. Banjarsari kota Surakarta, petugas kepolisian telah menemukan dan melakukan penyitaan barang bukti berupa : 1(satu) Unit HP merk Ever Cross warna putih Nomor IM3 : 085799500596 dan 1(satu) unit sepeda angin (onthel) warna biru. Benar shabu sebanyak 1(satu) paket kecil tersebut ditemukan oleh petugas kepolisian di samping tembok gapura diatas bata yang berjarak sekitar 2(dua) meter dari tersangka duduk di gapura, selanjutnya tersangka di minta mengambil lagi shabu tersebut oleh petugas kepolisian yang saat itu tersangka ambil lagi dengan tangan kanan tersangka kemudian tersangka di minta membuka isinya dan benar berisi shabu berbentuki serbuk Kristal putih seperti gula, kemudian shabu tersebut di sita petugas kepolisian dari tangan tersangka.

Untuk mengetahui apakah barang bukti tersangka mengadung narkotika, Sat Res Narkoba Polresta Surakarta meminta bantuan Laboratoris Kriminalistik dari Labfor Polri Cabang Semarang. Berupa Berita Acara Pemeriksaan laboratories Kriminalistik Nomor : 61 / NNF / 2017, tanggal 13 Januari 2017 yang intinya menyatakan bahwa benar barang bukti yang di kirim oleh penyidik berupa : 1(satu) paket / plastic kecil transparan berisi sabu adalah : positif mengandung METAMFETAMINA terdaftar dalam Golongan 1( satu) Nomor Urut 61 dalam lampiran UU RI Nomor 35 Tahun 2009 tentang Narkotika adalah merupakan pemenuhan 1 (satu) alat bukti petunjuk. $^{23}$

7) Penahanan

Penahanan bertujuan untuk kepentimgan penyidikan dan untuk kepentingan pemeriksaan hakim di persidangan. Dalam Pasal 20 KUHAP memberikan kewenagan kepada penyidik, penuntut umum atau hakim untuk melakukan penahanan atau penahanan lanjut dimana setiap kali melakukan penahanan tersebut harus memakai surat perintah penahanan.

Dalam perkara ini pihak penyidik melakukan penahanan terhadap tersangka Deden Darusman Alias Deden berdasarkan Surat Perintah Penahanan Nomor : Sp. Han / 07 /I / 2017 / Res Narkoba, tanggal 07 Januari 2017, telah dilakukan penahanan terhadap tersangka, tembusan surat perintah penahanan dikirimkan kepada keluarga tersangka dan dibuatkan

\footnotetext{
${ }^{23}$ Berkas Perkara, Op.Cit.
}

Proses Penyidikan Perkara Tindak Pidana Narkotika (Studi Kasus Sat Res Narkoba Polresta Surakarta) 
berita acara penahanan tertanggal 07 Januari 201. Dan waktu penahanan diperpanjang selama 40 hari.

Dengan Surat Perpanjang Penahanan dari Kejaksaan Negeri Surakarta Nomor : 18 / T4 / Euh. 1 / I / 2017 tanggal, 18 Januari 2017 telah dilakukan perpanjangan penahanan selama 40 (empat puluh) hari terhadap tersangka DEDEN DARUSMAN Alias DEDEN dan telah di buatkan berita acara pelaksanaan perpanjangan penahanan tertanggal, 27 Januari 2017 tembusan surat perpanjangan penahanan tersebut telah diberikan kepada tersangka atau keluarganya.

Berdasarkan hasil penyidikan dan kebenaran dan penemuan alat bukti dan barang bukti 1(satu) paket / plastic kecil transparan berisi shabu berat : 0,209 gram terhadap Deden Darusman Alian Deden dipersangkakan telah melanggar Pasal114 Ayat (1),Pasal 112 Ayat (1), Pasal 127 Ayat (1) huruf a Undang-Undang RI. Nomor 35 Tahun 2009, tentang Narkotika. ${ }^{24}$

8) Selesainya Penyidikan

Berita Acara Pemeriksaan adalah suatu rangkaian pemeriksaan yang dilakukan oleh penyidik dalam mengusut suatu tindak pidana. Setelah penyidik menganggap bahwa pemeriksaan terhadap suatu tindak pidana telah cukup, maka penyidik atas kekuatan sumpah jabatannya ini sekaligus pila dilampirkan semua berita acara yang dibuat sehubungan dengan tindakan-tindakan yang diperlukan dalam rangkaian penyidikan.

Setelah lengkap semua berita acara diperlukan, maka penyidik menyerahkan berkas tesebut kepada penuntut umum yang merupakan penyerahan dalam tahap pertama yaitu hanya berkas perkaranya saja. ${ }^{25}$

Dalam hal penyidikan yang dilakukan oleh Sat Res Narkoba Polresta Surakarta sudah dianggap selesai, penyidik menyerahkan tanggung jawab atas tersangka Deden Darusman Alias Deden barang bukti 1(satu) paket / plastic kecil transparan berisi shabu, 1(satu) Unit HP merk Ever Cross warna Putih nomor IM3 085799500596, 1(satu) Unit sepeda angin (onthel) warna biru, Sesobek tissue warna putih, Sepotong isolasi warna bening kepada Kejaksaan Negeri Surakarta. ${ }^{26}$

Penyidikan dianggap selesai apabila dari Kejaksaan Negeri Surakarta tidak mengembalikan hasil penyidikan atau apabila sebelum batas waktu tersebut telah ada pemberitahuan tentang hal itu. ${ }^{27}$

\section{Kendala-Kendala Yang Dihadapi Oleh Penyidik Dalam Melakukan Penyidikan Terhadap Tindak Pidana Narkotika.}

Proses penyidikan tindak pidana narkotika yang dilakukan oleh Sat Res Narkoba Polresta Surakarta sudah sesuai dengan prosedur yang ada mulai dari tahap penyelidikan sampai ke tahap penyidikan. Tetapi pada saat melakukan penyidikan Sat

\footnotetext{
${ }^{24}$ Ibid.

${ }^{25}$ Andi Tentri Wali Putri Takdir Patarai, Op.Cit. hal.81.

${ }^{26}$ Berkas Perkara,Op.Cit.

${ }^{27}$ Andi Tentri Wali Putri Takdir Patarai,Op.Cit.hal.82.
}

Proses Penyidikan Perkara Tindak Pidana Narkotika (Studi Kasus Sat Res Narkoba Polresta Surakarta) 
Res Narkoba Polresta Surakarta ada beberapa kendala yaitu seperti yang di katakan oleh beberapa anggota kepolisian yaitu :

1. Menurut Kompol Edy Sulistyanto. Tentang hambatan yang dihadapi penyidik dalam melakukan penyidikan tindak pidana narkotika adalah: kendala saat di lapangan yaitu jarang masyarakat yang mau menginformasikan tentang pengguna narkotika kepada polisi, biasanya petugas mencari informasi sendiri dengan jalan surveillence penyidikan yaitu dengan cara penyamaran, dengan mencari informasi yaitu dengan orang umum atau awam dengan menjadikan orang tersebut informan untuk mendapatkan informasi. ${ }^{28}$

2. Menurut AIPDA Warsino. Tentang hambatan yang dihadapi penyidik dalam melakukan penyidikan tindak pidana narkotika yaitu tersangka saat di Berita Acara Periksaan (BAP) atau saat di wawancarai ternyata tersangka mengalami sakau yaitu dengan menjedor-jedorkan kepalanya ke pintu jadi tersangka harus di damping oleh ahli kejiwaan atau psikolog, soalnya jika tersangka seperti itu penyidik tidak biasa mewawancarai. ${ }^{29}$

3. Menurut Bripka Bayu Prayudanto. Tentang hambatan yang dihadapi penyidik dalam melakukan penyidikan tindak pidana narkotika yaitu jarang masyarakat yang mau menginformasikan bahwa ada pengguna narkotika kepada kepolisian. ${ }^{30}$

4. Menurut Kompol Widodo. Tentang hambatan yang dihadapi penyidik dalam melakukan penyidikan tindak pidana narkotika yaitu sebenarnya tidak ada hambatan asalkan tersangkanya sudah tertangkap. ${ }^{31}$

Berdasarkan hasil dari proses penyidikan tindak pidana narkotika Golongan I berupa Shabu yang tersangkanya Deden Darusman Alias Deden ini, pihak kepolisian masih mengalami kendala,terutama dalam melacak pengedarnya atau penjualnya dan pembelinya, dalam kasus ini pengedar atau penjualnya adalah Johan (belum tertangkap) dan pembelinya adalah Gendut yang juga (belum tertangkap) dan dalam kasus ini Deden sebagai pembeli utama atau perantara membelikan atau mencarikan shabu Gendut dari Johan (belum tertangkap) dengan perantara Muhammad Taufiq Romadhon Alias Temon yang hanya menghubungkan Deden dengan Johan dengan cara Temon (saksi) telah dimintai tolong Deden (tersangka) untuk SMS kepada Johan untuk datang ke rumah Temon (saksi) karena Deden mau beli shabu dan setelah Deden membeli shabu kepada Johan (belum tertangkap) Deden akan memberikian shabu yang dibelinya tersebut kepada Gendut (belum tertangkap). ${ }^{32}$

Berdasarkan hasil penelitian mengenai kendala yang dihadapi saat melakukan proses penyidikan terhadap tindak pidana narkotika dengan tersangka Deden Darusman Alias Deden, peneliti berpendapat bahwa dalam pengungkapan kasus tindak pidana narkotika, merupakan kasus yang cukup sulit untuk diungkapkan. Kesulitan dalam mengungkap kasus tersebut, karena pada saat Deden melakukan transaksi dengan Johan lewat Hp dan pihak kepolisian pada saat ingin meminta nomor Hp Johan ternyata Hp Temon telah jatuh saat pengejaran dan pihak petugas

\footnotetext{
${ }^{28}$ Kompol. Edy Sulistyanto, Loc. Cit.

${ }^{29}$ Aipda. Warsino, Loc. Cit.

${ }^{30}$ Bripka. Bayu Prayudanto, Loc. Cit.

${ }^{31}$ Kompol. Widodo, Loc. Cit.

${ }^{32}$ Dalam Berkas Perkara. No : B/89/I/2017/Res Narkoba.
}

Proses Penyidikan Perkara Tindak Pidana Narkotika (Studi Kasus Sat Res Narkoba Polresta Surakarta) 
sempat mencari Hp Temon tapi tidak ketemu karena pada saat Temon (saksi) lari ada banyak orang jalan pas ada orang pulang pengajian. Dan Temon (saksi) ataupun Deden (tersangka) tidak mengetahui rumah Johan (belum tertangkap). Begitu juga dengan masyarakat untuk dimintai keterangan atau informasi malah sering kali saling lempar-lemparan, terkadang warga masyarakat menjawab tidak tau. ${ }^{33}$

Jadi dapat disimpulkan bahwa kendala yang dihadapi oleh penyidik saat melakukan penyidikan adalah banyak atau jarang masyarakat yang mau memberikan informasi terhadap anggota kepolisian bahwa ada orang yang menggunakan narkotika.

\section{KESIMPULAN}

Berdasarkan uraian/pembahasan yang telah diuraikan diatas, maka penulis dapat menarik kesimpulan mengenai Proses Penyidikan Perkara Tindak Pidana Narkotika (Studi Kasus Satuan Reserse Narkoba Polresta Surakarta) sebagai berikut:

1. Proses penyidikan perkara tindak pidana narkotika (Studi Kasus Satuan Reserse Narkoba Polresta Surakarta) yaitu menerima Laporan dari masyarakat adanya dugaan tindak pidana Narkotika kemudian Sat Res Narkoba Polresta Surakarta membuat Laporan Polisi terhadap laporan tersebut setelah itu dibuatkan Surat Perintah Penyidikan dan Surat Perintah Tugas kemudian Anggota Sat Res Narkoba Polresta Surakarta melakukan tindakan pertama pada tempat kejadian dan ditemukan saudara Deden Darusman Alias Deden sedang membawa shabu sehingga Anggota Sat Res Narkoba Polresta Surakarta melakukan upaya paksa terhadap saudara Deden Darusman Alias Deden berupa penangkapan, penggeledahan dan penyitaan terhadap barang bukti, selanjutnya dilakukan Gelar Perkara untuk menganalisis penerapan Pasal yang akan disangkakan terhadap saudara Deden Darusman Alias Deden, setelah itu melengkapi administrasi penyidikan (membuat Surat Perintah Penyidikan) kemudian saudara Deden Darusman Alias Deden dilakukan Pemeriksaan sebagai tersangka (Penyidik membuat Berita Acara Pemeriksaan), selanjutnya saudara Deden Darusman Alias Deden dilakukan Penahanan selama 20 (dua puluh) hari dan dilakukan perpanjangan penahanan oleh Kejaksaan Negeri Surakarta selama 40 (empat puluh) hari. Kemudian dalam proses Penahanan, Penyidik melengkapi Berkas Perkara dan mengirim berkas perkara tersebut dinyatakan telah lengkap (P-21), setelah itu dilakukan tahap pengiriman tersangka ke Kejaksaan Negeri Surakarta.

2. Kendala yang dihadapi oleh penyidik dalam melakukan proses penyidikan terhadap tindak pidana narkotika yaitu :

a. Jarang masyarakat yang mau menginformasikan adanya tindak pidana narkotika.

b. Pada saat di Berita Acara Pemeriksaan (BAP) atau saat diwawancarai ternyata tersangka mengalami sakau.

\section{Saran}

Merujuk pada kesimpulan di atas, maka penulis yang dapat dikemukakan adalah :

\footnotetext{
${ }^{33}$ Ibid.
}

Proses Penyidikan Perkara Tindak Pidana Narkotika (Studi Kasus Sat Res Narkoba Polresta Surakarta) 
1. Hendaknya penyidik dari Sat Res Narkoba Polresta Surakarta juga mengikut sertakan penyidik Pejabat Pegawai Negeri Sipil dari lingkungan Dinas Kesehatan Surakarta. Hal ini diharapkan dapat terlaksana karena adanya penyidik PNS dari Dinas Kesehatan Surakarta,maka proses penyidikan akan lebih optimal. Selama ini yang terjaring dalam razia hanya yang tertangkap tangan membawa narkotika, namun jika penyidik PNS dari lingkungan Dinas Kesehatan Surakarta diikutsertakan maka pada saat razia sekaligus dapat juga dilakukan tes urine yang dapat membuktikan seseorang yang terjaring dalam razia tersebut pemakai atau bukan. Pejabat Pegawai Negeri Sipil dari lingkungan Dinas Kesehatan Kota Surakarta, hendaknya juga melengkapi sarana dan prasarananya guna mendukung proses penyidikan perkara tindak pidana narkotika yang dilakukan oleh penyidik dari Satuan Reserse Narkoba Polresta Surakarta, misalnya dengan melengkapi sarana laboratorium berjalan.

2. Diharapkan masyarakat untuk menginformasikan atau lebih berpartisipasi dalam membantu kinerja para penyidik dalam menanggulangi tindak pidana narkotika, yang antar lain masyarakat diharapkan dapat membantu dalam hal penangkapan tersangka dan tidak menutup-nutupi kebenaran tersangka meskipun mereka adalah anggota keluarga sendiri.

\section{DAFTAR PUSTAKA}

Buku/Jurnal :

Andi Tentri Wali Putri Takdir Patarai. Proses Penyidikan Tindak Pidana Penyalahgunaan Narkotika.2013, No.1. Artikel dalam Jurnal Hukum Acara Pidana.

Berkas Perkara. No. B/89///2017/Res Narkoba.

Peraturan Perundang-undangan:

Undang-Undang No. 35 Tahun 2009 Tentang Narkotika

Internet:

Anonim. "Metode Penelitian". (On-line), diakses di: https://idtesis.com/metodepenelitian-hukum-empiris-dan-normatif/. (21 Januari 2013).

Yudo Saputra. "Pengertian Penahanan dan Penangkapan". (On-line), diakses di: http://Yudosaputra91.blogspot.co.id/2013/04/pengertian-penahanan-dan penangkapan.html? $m=1$. (08 April 2013). 